\title{
Pien Tze Huang suppresses the stem-like side population in colorectal cancer cells
}

\author{
LIHUI WEI ${ }^{1,2}$, PANGYU CHEN ${ }^{1,2}$, YOUQIN CHEN ${ }^{3}$, ALING SHEN $^{1,2}$, HONGWEI CHEN $^{1,2}$, \\ WEI LIN ${ }^{1,2}$, ZHENFENG HONG ${ }^{1}$, THOMAS J. SFERRA ${ }^{3}$ and JUN PENG ${ }^{1,2,4}$ \\ ${ }^{1}$ Academy of Integrative Medicine and ${ }^{2}$ Fujian Key Laboratory of Integrative Medicine on Geriatrics, \\ Fujian University of Traditional Chinese Medicine, Fuzhou, Fujian 350122, P.R. China; \\ ${ }^{3}$ Rainbow Babies and Children's Hospital, Case Western Reserve University School of \\ Medicine, Cleveland, OH 44106, USA; ${ }^{4}$ Postdoctor Workstation, Zhangzhou Pien Tze Huang \\ Pharmaceutical Co., Ltd., Shangjie, Zhangzhou, Fujian 363000, P.R. China
}

Received July 19, 2013; Accepted October 18, 2013

DOI: $10.3892 / \mathrm{mmr} .2013 .1760$

\begin{abstract}
Accumulating evidence suggests that a small population of cells termed cancer stem cells (CSCs) are crucial in tumor development and drug resistance, leading to cancer relapse and metastasis and eventually the failure of clinical cancer treatment. Therefore, targeting CSCs is a promising approach for anticancer therapies. Due to the drug resistance and adverse effects of currently used chemotherapies, traditional Chinese medicines (TCM) have recently received attention due to the relatively few side-effects. Thus, they have been used as important alternative remedies for various diseases, including cancer. Pien Tze Huang (PZH), a well-known TCM formula that was first prescribed more than 450 years ago in the Ming Dynasty, has been used in China and Southeast Asia for centuries as a folk remedy for various types of cancer. Previously, it was reported that $\mathrm{PZH}$ inhibits colon cancer growth via the promotion of cancer cell apoptosis and inhibition of cell proliferation and tumor angiogenesis, which is probably mediated by its regulatory effect on multiple intracellular signaling pathways. To elucidate the mechanism of the tumoricidal activity of $\mathrm{PZH}$, the aim of the present study was to investigate the effect of PZH on CSCs that were isolated as the side population (SP) from the HT-29 colorectal cancer cell line. The results demonstrated that PZH significantly and dose-dependently
\end{abstract}

Correspondence to: Dr Jun Peng, Academy of Integrative Medicine, Fujian University of Traditional Chinese Medicine, 1 Huatuo Road, Minhou Shangjie, Fuzhou, Fujian 350122, P.R. China

E-mail: pjunlab@hotmail.com

Abbreviations: CRC, colorectal cancer; PZH, Pien Tze Huang; CSCs, cancer stem cells; SP, side population

Key words: Pien Tze Huang, traditional Chinese medicine, colorectal cancer, cancer stem cells, side population reduced the percentage of the colorectal cancer stem-like SP cells, decreased the viability and sphere-forming capacity of HT-29 SP cells, indicating that PZH is potent in suppressing the growth of colorectal cancer stem cells. Moreover, PZH treatment in HT-29 SP cells markedly inhibited the mRNA levels of $\mathrm{ABCB} 1$ and $\mathrm{ABCG} 2$, which are members of the $\mathrm{ABC}$ transporter superfamily, thereby contributing to the SP phenotype and multi-drug resistance. Findings of the present study suggest that inhibiting the growth of CSCs is a potential mechanism by which PZH can be used in cancer treatment.

\section{Introduction}

Colorectal cancer (CRC) is one of the most common malignancies, with over one million new cases and more than half a million deaths each year worldwide $(1,2)$. Although complete resection of the tumor is the best prognosis for long-term survival, CRC patients frequently present with metastatic disease at the time of their diagnosis, and surgery cannot always extirpate the recurrence of advanced CRC $(3,4)$. Therefore, chemotherapy remains one of the major therapeutic approaches for patients with invasive and metastatic CRC, with 5-fluorouracil (5-FU)-based regimens being considered as standard chemotherapy treatment. However, due to drug resistance and unacceptable levels of toxicity against normal cells, systemic chemotherapy using 5-FU-based regimens produces objective response rates of only $10-20 \%$ (5-8). Thus, novel therapeutic strategies should be developed and antitumor agents should be identified.

Malignant tumors arise from a small fraction of cancer cells that possess stem cell features and are therefore termed cancer stem cells (CSCs) (9). The existence of CSCs has been demonstrated in the majority of leukemias and many solid tumors including CRC (10-14). Similar to normal stem cells, CSCs possess properties of continuous self-renewal and multidirectional differentiation, which confers CSCs the ability of unlimited proliferation facilitating the long-term maintenance of the cancer, and differentiation into different cell types to develop new tumors (15). More importantly, it has been 
shown that CSCs are naturally resistant to chemotherapeutic agents through various mechanisms (16). CSCs specifically overexpress the ATP-binding cassette (ABC) family of transporter proteins such as $\mathrm{ABCB} 1$ and $\mathrm{ABCG} 2$, which pump various xenobiotics out of the cell, reducing the intracellular accumulation of chemotherapeutic drugs (17-19). In addition, CSCs usually contain high levels of DNA repair mechanism and anti-apoptotic proteins such as Bcl-2 and survivin, further conferring CSCs a survival advantage $(20,21)$. CSCs also exhibit relative cell cycle quiescence resulting in a slow rate of cell turnover, thereby assisting CSCs to evade the cytotoxic effects of conventional chemotherapies that are designed to target rapidly replicating cells $(22,23)$. Therefore, CSCs are, not only responsible for tumor initiation and progression, but also play important roles in drug resistance leading to cancer relapse and metastasis and eventually the failure of clinical treatment. Thus, targeting CSCs is a promising approach for anticancer treatments.

Due to the drug resistance and cytotoxicity of currently used chemotherapies, traditional Chinese medicines (TCM) have received attention due to few side-effects as compared to modern chemotherapeutics and have been used for thousands of years as important alternative remedies for various diseases $(24,25)$. TCM formula is a complex combination of many natural products, each of which contains numerous chemical compounds. TCM formulas therefore are considered to be multi-component and multi-target agents that exert their therapeutic activities in a more holistic way. Pien Tze Huang $(\mathrm{PZH})$ is a well-known TCM formula that was first prescribed by a royal physician $>450$ years ago in the Ming Dynasty. The main ingredients of PZH include Moschus, Calculus Bovis, Snake Gall and Radix Notoginseng. These products together confer PZH properties of heat-clearing, detoxification, promotion of blood circulation, reduction of blood stasis, dissipation of hard mass, detumescence and analgesia (26). In the TCM system, accumulation of toxic dampness and heat is one of the major causative factors in the pathogenesis of cancers, and therefore clearing heat and detoxification is a principle of anticancer treatment. Thus PZH, which has also been used in China and Southeast Asia for centuries as a folk remedy for various types of cancer, is believed to be effective for anticancer treatment. Modern pharmacological studies suggested that PZH exhibits therapeutic effects in clinical trials of tumors such as hepatocellular carcinoma and colon cancer $(27,28)$. In addition, in experimental animals PZH inhibits the growth of Ehrlich-Ascites tumor, gastric carcinoma, and hepatoma (29). Moreover, it was reported that PZH inhibits colon cancer growth in vivo and in vitro via the promotion of cancer cell apoptosis and inhibition of cell proliferation and tumor angiogenesis, which is probably mediated by its regulatory effect on multiple intracellular pathways (30-35). To elucidate the mechanism of the tumoricidal activity of PZH, the effect of $\mathrm{PZH}$ on colorectal cancer stem cells was investigated.

\section{Materials and methods}

Materials and reagents. Dulbecco's modified Eagle's medium (DMEM), fetal bovine serum (FBS), B27 supplement (50X), penicillin-streptomycin, trypsin-EDTA and TRIzol reagent were purchased from Invitrogen (Carlsbad, CA, USA).
SuperScript II reverse transcriptase was obtained from Promega (Madison, WI, USA). Any other chemicals used, unless otherwise stated, were obtained from Sigma Chemicals (St. Louis, MO, USA).

Preparation of $\mathrm{PZH}$. PZH was obtained from and authenticated by Zhangzhou Pien Tze Huang Pharmaceutical Co., Ltd., China (Chinese FDA approval no. Z35020242). Stock solution of PZH was prepared immediately prior to use by dissolving the $\mathrm{PZH}$ powder in phosphate-buffered saline (PBS) to a concentration of $40 \mathrm{mg} / \mathrm{ml}$. The working concentrations of PZH were obtained by diluting the stock solution in the culture medium.

Cell culture. Human colon carcinoma HT-29 cells were obtained from the Cell Bank of the Chinese Academy of Sciences (Shanghai, China). The cells were grown in DMEM containing $10 \%$ (v/v) FBS, and $100 \mathrm{U} / \mathrm{ml}$ penicillin and $100 \mu \mathrm{g} / \mathrm{ml}$ streptomycin in a $37^{\circ} \mathrm{C}$ humidified incubator with $5 \% \mathrm{CO}_{2}$.

Side population analysis. Based on the protocol by Goodell et al (36), HT-29 cells were digested with $0.25 \%$ trypsin-EDTA, and resuspended in DMEM culture (supplemented with $2 \%$ FBS) at a concentration of $2.5 \times 10^{6}$ cells $/ \mathrm{ml}$. Fresh Hoechst 33342 dye (10 $\mu \mathrm{g} / \mathrm{ml}$; final concentration) was added for $30 \mathrm{~min}$ at $37^{\circ} \mathrm{C}$ in a rotary shaker. As a control, some cells were incubated with Hoechst 33342 dye in the presence of $50 \mu \mathrm{M}$ verapamil. At the end of incubation, the cells were washed and resuspended in cold PBS, $1 \mathrm{mg} / \mathrm{ml}$ propidium iodide was added, and the cells were kept at $4^{\circ} \mathrm{C}$ in the dark. Cell analysis and sorting were performed on Moflo XDP ${ }^{\text {тм }}$ cell sorter flow cytometry (Beckman Coulter, Fullerton, CA, USA). Excitation of Hoechst dye was performed using a UV laser at $355 \mathrm{~nm}$, and the fluorescence was measured with a $450 \pm 25 \mathrm{~nm}$ filter (Hoechst blue) and a $620 \pm 15 \mathrm{~nm}$ filter (Hoechst red). Doublets and dead cells were gated out. Inhibition of the SP phenotype by verapamil was used as guidance for drawing of sorting gates.

Stem cell culture. Stem cells were cultured in serum-free stem cell culture medium, which contains DMEM/F12 culture medium, B27 (1X), $20 \mathrm{ng} / \mathrm{ml} \mathrm{EGF} \mathrm{and} 20 \mathrm{ng} / \mathrm{ml} \mathrm{bFGF,} \mathrm{to}$ prevent differentiation of the stem cells.

Sphere formation assay. Sorted cells were seeded at a density of 1,000 cells/well in 6-well plates (Corning, Lowell, MA, USA) and cultured in the above-mentioned serum-free stem cell culture medium in a humidified incubator $\left(5 \% \mathrm{CO}_{2}\right)$ at $37^{\circ} \mathrm{C}$. The medium was added every 3 days. When the spheroids sufficiently large ( $>50$ cells within a sphere was considered to be a full sphere), they were collected and transferred onto a 96-well dish, and images were captured by BD Pathway ${ }^{\mathrm{TM}}$ 855 under $\times 10$ objective in the form of 10x10 montage (BD Biosciences Bioimaging, Rockville, MD, USA).

Cell viability evaluation. Cell viability was assessed by the WST-1 assay. HT-29 stem-like cells (20,000/well in 96-well plates) were incubated with the above-mentioned serum-free stem cell culture medium at $37^{\circ} \mathrm{C}$ for $48 \mathrm{~h}$. The cells were then 

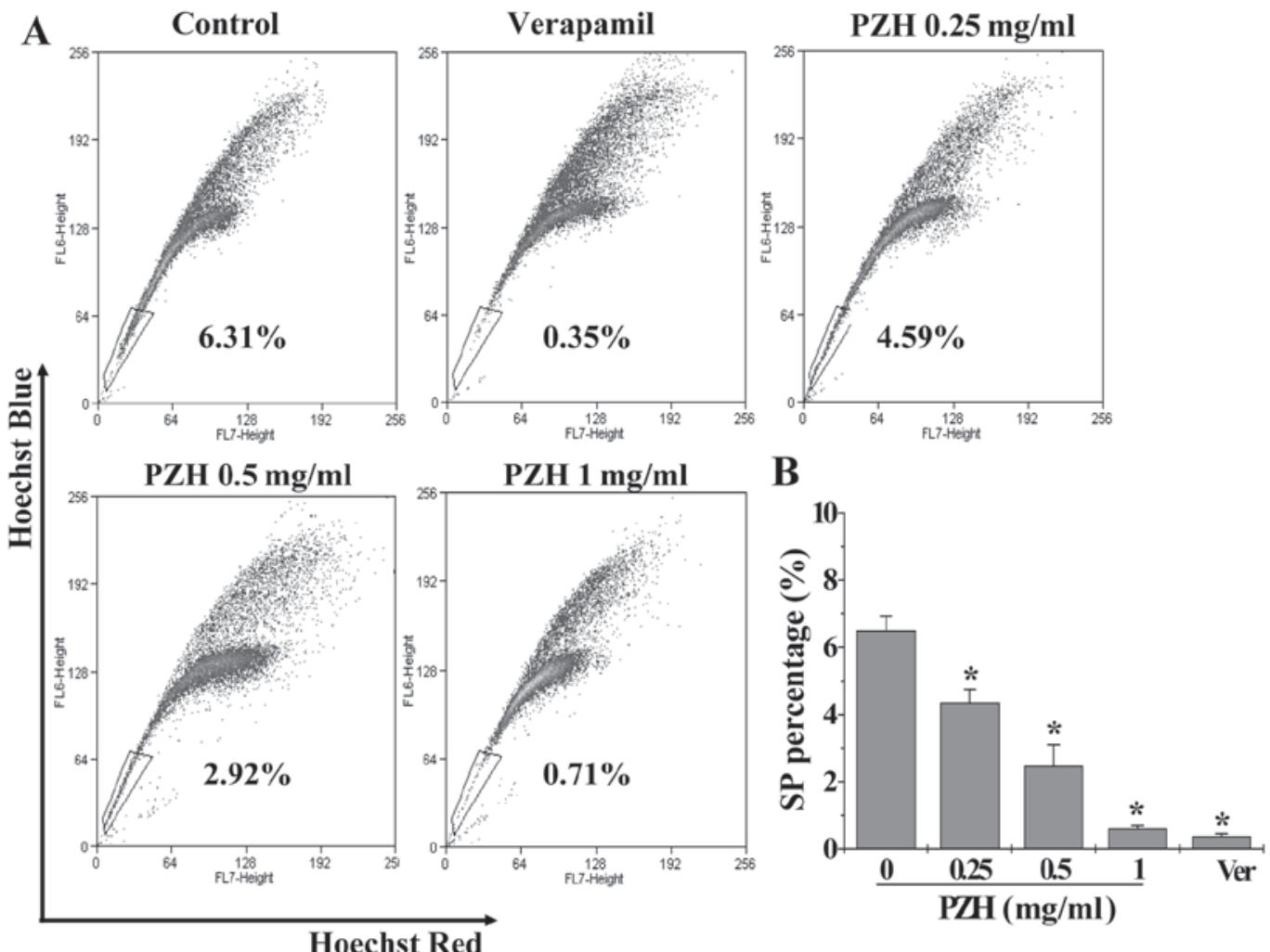

Figure 1. Effect of Pien Tze Huang (PZH) on the percentage of side population (SP) in human colorectal cancer HT-29 cells. (A) Subsequent to treatment with various concentrations of PZH for $24 \mathrm{~h}, \mathrm{HT}-29$ cells were stained with Hoechst 33342 and percentages of SP were analyzed by FACS. As an ABC transporter inhibitor, verapamil was used for the confirmation of SP identity. (B) Quantification of FACS analysis. Data are expressed as the average with SD (error bars) from three independent experiments. ${ }^{*} \mathrm{P}<0.05$, vs. untreated control cells.

A

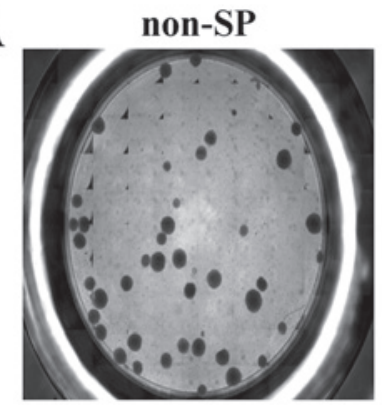

B

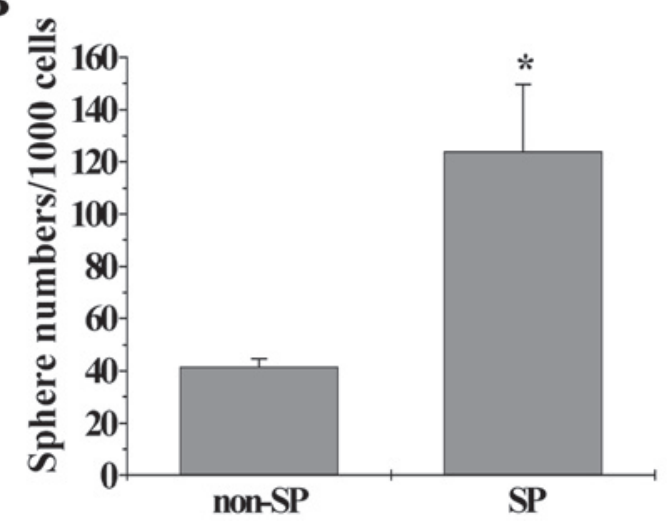

C non-SP SP
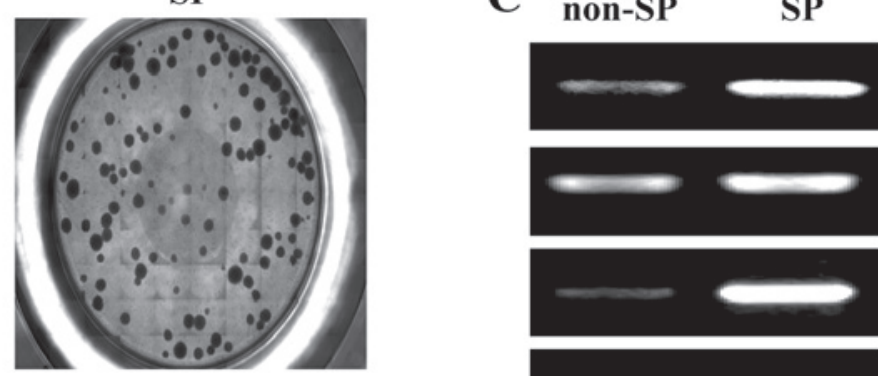

CD44

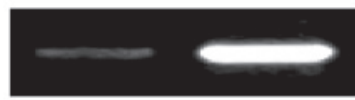

Oct 4

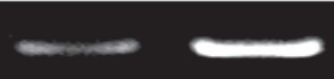

ABCB1

GAPDH

Figure 2. Phenotypic identification. (A) Sphere-formation ability of sorted side population (SP) and non-SP cells was analyzed. Cells were seeded at a density of 1,000 cells/well and grown in serum-free stem cell culture medium. After 15 days, when the spheroids were sufficiently large ( $>50$ cells), they were counted and photographed. (B) Quantification of sphere formation analysis. Data are shown as averages with SD (error bars) from three independent experiments. ${ }^{*} \mathrm{P}<0.05$. (C) The mRNA levels of CD133, CD44, Oct4 and ABCB1 in SP cells and non-SP cells were determined by RT-PCR. GAPDH was used as the internal control. Images are representative of three independent experiments. 
A
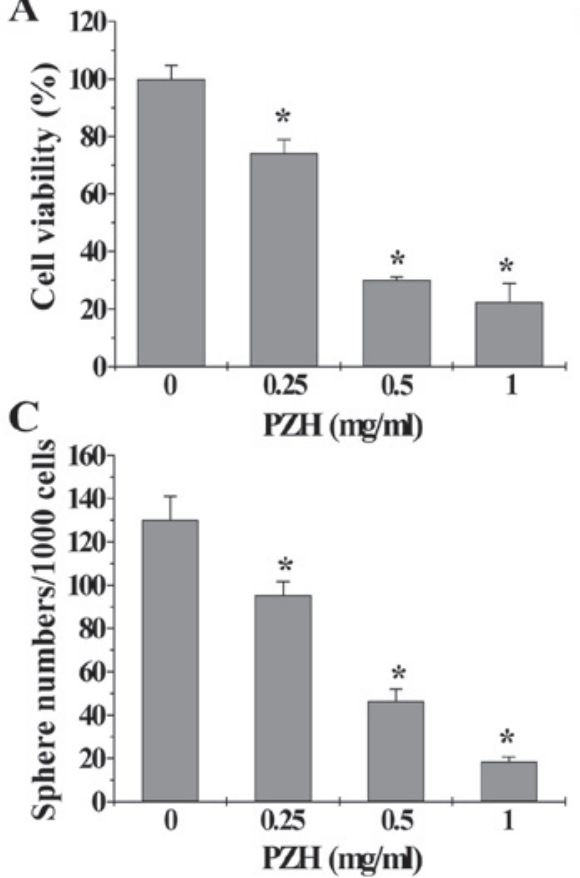

B
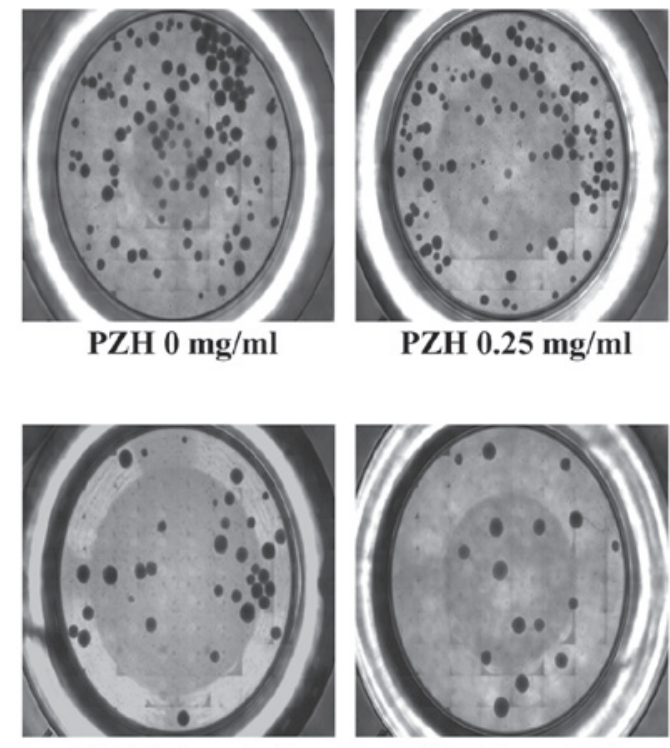

PZH $0.5 \mathrm{mg} / \mathrm{ml}$

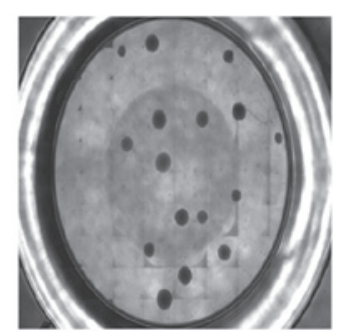

PZH $1 \mathrm{mg} / \mathrm{ml}$

Figure 3. Effect of Pien Tze Huang (PZH) on the growth of isolated HT-29 side population (SP) cells. (A) SP cells were treated with the indicated concentrations of PZH for 24 h. Cell viability was determined by WST-1 assay. Data are averages with SD (error bars) from three independent experiments. "P<0.05, vs. untreated control cells. (B) After treatment with the indicated concentrations of PZH for $24 \mathrm{~h}$, the sphere-formation capacity of SP cells was analyzed (C) Quantification of sphere formation analysis. Data are shown as averages with SD (error bars) from three independent experiments. ${ }^{*} \mathrm{P}<0.05$, vs. untreated control cells.

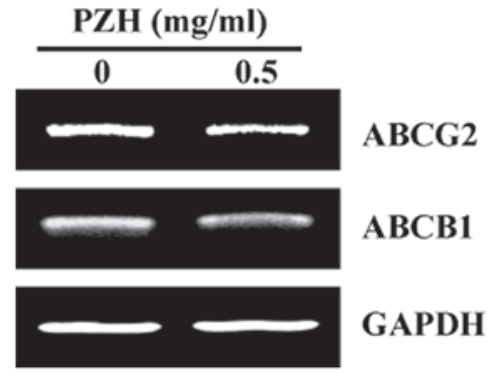

Figure 4. Effect of Pien Tze Huang (PZH) on the mRNA expression of $\mathrm{ABCB} 1$ and $\mathrm{ABCG} 2$ in isolated HT-29 SP cells. Following treatment with $0.5 \mathrm{mg} / \mathrm{ml}$ of PZH for $24 \mathrm{~h}$, the mRNA levels of ABCB1 and ABCG2 in isolated HT-29 SP cells were determined by RT-PCR. GAPDH was used as the internal control. Images are representative of three independent experiments.

treated with various concentrations of PZH for $24 \mathrm{~h}$. At the end of the treatment, $10 \mu \mathrm{l}$ WST-1 was added to each well, and the samples were incubated for an additional $2 \mathrm{~h}$ at $37^{\circ} \mathrm{C}$. The absorbance was measured at $450 \mathrm{~nm}$ using an ELISA reader (Model ELX800, BioTek, USA).

RT-PCR analysis. Total RNA was isolated with TRIzol reagent. Oligo(dT)-primed RNA $(1 \mu \mathrm{g})$ was reverse-transcribed with SuperScript II reverse transcriptase (Promega) according to the manufacturer's instructions. The obtained cDNA was used to determine the mRNA amount of CD133, CD44, Oct4, ABCB1, ABCG2 by PCR. GAPDH was used as an internal control.

Statistical analysis. Data were analyzed using the statistical software SPSS13.0. Statistical analysis of the data was performed using the Student's t-test and one-way analysis of variance (ANOVA). $\mathrm{P}<0.05$ was considered statistically significant.

\section{Results and Discussion}

Human colorectal cancer cell line HT-29 contains stem-like side population cells. One of the commonly used techniques for the identification and isolation of CSCs is the flow cytometric side population (SP) analysis (37), which is based on the ability of CSCs to efflux Hoechst dye due to the overexpression of ABC transporter proteins (17-19). SP cells have been identified in various types of cancer including CRC; and cells in SP exibit stem cell-like characteristics, such as the ability for self-renewal and tumorigenicity (38-46). Moreover, it has been shown that the percentage of SP cells in tumors is correlated with tumor grade and patient prognosis (46). Therefore, in the present study, the stem-like cells from the CRC HT-29 cell line were isolated as SP using fluorescence-activated cell sorting (FACS) after staining with Hoechst 33342. As shown in Fig. 1, the percentage of SP in HT-29 cells was $6.50 \pm 0.42 \%$. Following treatment with verapamil, a multi-drug transporter inhibitor, the SP was reduced to $0.38 \pm 0.08 \%(\mathrm{P}<0.05)$.

To determine whether the SP cells were enriched for cancer stem cells (CSCs), the ability of the SP cells to undergo in vitro sphere formation was examined. The results in Fig. $2 \mathrm{~A}$ show that the SP cells had a higher ability to undergo sphere formation compared with non-SP cells after 15 days in culture $(\mathrm{P}<0.05)$. To verify these observations, an RT-PCR assay was performed to analyze the expression of proteins that are either CSC surface markers or specifically and/or highly expressed 
in CSCs (CD133, CD44, Oct4 and ABCB1). As shown in Fig. 2B, the mRNA expression level of CD133, CD44, Oct4 and ABCB1 in SP cells was markedly higher than that in non-SP cells. Taken together, these data suggest that human colorectal cancer HT-29 cells contain a stem-like population.

PZH reduces the percentage of SP in HT-29 cells. CSCs are naturally resistant to conventional chemotherapy treatments, leading to cancer relapse and metastasis and eventually the failure of clinical anticancer treatment. Therefore, development of novel therapeutic agents targeting CSCs holds hope for improvement of effectiveness of anticancer therapies. Natural products, including traditional Chinese medicine (TCM), have long been used as alternative remedies for cancer. Recently, natural products received attention in stem cell biology as some compounds have been reported to attack cancer stem-like cells as well as to improve the efficacy of conventional chemotherapies $(47,48)$. PZH is a well-known TCM formula that has been used to clinically treat various types of cancer. Previous studies have reported that PZH likely exerts its anticancer activities via the modulation of multiple intracellular signaling pathways (30-35). To elucidate the mechanism of the tumoricidal activity of $\mathrm{PZH}$, its effect was evaluated on colorectal cancer stem-like cells by examining the size of SP in HT-29 cells following treatment with various concentrations of PZH. As shown in Fig. 1, the percentage of SP cells following treatment with $0,0.25,0.5$ and $1 \mathrm{mg} / \mathrm{ml}$ of PZH was $6.50 \pm 0.42,4.35 \pm 0.39,2.47 \pm 0.64$ and $0.61 \pm 0.09 \%$, respectively ( $\mathrm{P}<0.05$, vs. untreated control cells), suggesting that $\mathrm{PZH}$ possesses anti-CSC activity.

PZH inhibits the viability and sphere formation capacity of SP in HT-29 cells. To determine the effect of PZH on the growth of colorectal cancer stem-like cells, we treated isolated HT-29 SP cells with PZH and then examined cell viability via WST-1 assay. As shown in Fig. 3A, treatment with $0.25-1 \mathrm{mg} / \mathrm{ml}$ of PZH for $24 \mathrm{~h}$ dose-dependently reduced the viability of HT-29 SP cells by $26.83-77.67 \%$ compared with the untreated control cells $(\mathrm{P}<0.05)$. To confirm the growth suppressive activity of $\mathrm{PZH}$ in cancer stem-like cells, we investigated its effect on the sphere formation ability of SP cells. Data in Fig. 3B and C show that PZH dose-dependently suppressed sphere formation in isolated HT-29 SP cells $(\mathrm{P}<0.05)$. These results demonstrate that $\mathrm{PZH}$ is potent in suppressing the growth of colorectal cancer stem cells.

$P Z H$ inhibits the expression of $A B C B 1$ and $A B C G 2$ of SP in HT-29 cells. ATP-binding cassette (ABC) transporter proteins belong to the superfamily of membrane pumps that expel various xenobiotics out of cells, such as chemotherapeutic drugs and lipophilic fluorescent dyes, contributing to the SP phenotype and chemotherapy resistance. ABC transporters are commonly overexpressed in multi-drug-resistant tumors and CSCs. To explore the mechanism whereby PZH inhibited the growth of colorectal cancer stem-like cells, we examined the mRNA expression of ABCB1 and ABCG2, which are considered the best-characterized $\mathrm{ABC}$ members. Results from RT-PCR showed that PZH treatment markedly reduced the mRNA levels of ABCB1 and ABCG2 in HT-29 SP cells (Fig. 4).
In conclusion, our findings in this study suggest that attacking CSC is a potential mechanism by which $\mathrm{PZH}$ exerts its anticancer activities.

\section{Acknowledgements}

This study was sponsored by the National Natural Science Foundations of China (nos. 81073097 and 81202790) and the China Postdoctoral Science Foundation (no. 2013T60636).

\section{References}

1. Jemal A, Bray F, Center MM, Ferlay J, Ward E and Forman D: Global cancer statistics. CA Cancer J Clin 61: 69-90, 2011.

2. Markowitz SD and Bertagnolli MM: Molecular origins of cancer: molecular basis of colorectal cancer. N Engl J Med 361: 2449-2460, 2009.

3. Cunningham D, Atkin W, Lenz HJ, Lynch HT, Minsky B, Nordlinger B and Starling N: Colorectal cancer. Lancet 375: 1030-1047, 2010

4. Jiang WQ, Fu FF, Li YX, Wang WB, Wang HH, Jiang HP and Teng LS: Molecular biomarkers of colorectal cancer: prognostic and predictive tools for clinical practice. J Zhejiang Univ Sci B 13: 663-675, 2012.

5. Van Cutsem E and Costa F: Progress in the adjuvant treatment of colon cancer: has it influenced clinical practice? JAMA 294: 2758-2760, 2005.

6. Longley DB, Allen WL and Johnston PG: Drug resistance, predictive markers and pharmacogenomics in colorectal cancer. Biochim Biophys Acta 1766: 184-196, 2006.

7. Lippman SM: The dilemma and promise of cancer chemoprevention. Nat Clin Pract Oncol 3: 523, 2006.

8. Lin L, Liu Y, Li H, Li PK, Fuchs J, Shibata H, Iwabuchi Y and Lin J: Targeting colon cancer stem cells using a new curcumin analogue, GO-Y030. Br J Cancer 105: 212-220, 2011.

9. Reya T, Morrison SJ, Clarke MF and Weissman IL: Stem cells, cancer, and cancer stem cells. Nature 414: 105-111, 2001.

10. Lapidot T, Sirard C, Vormoor J, Murdoch B, Hoang T, Caceres-Cortes J, Minden M, Paterson B, Caligiuri MA and Dick JE: A cell initiating human acute myeloid leukaemia after transplantation into SCID mice. Nature 367: 645-648, 1994.

11. Al-Hajj M, Wicha MS, Benito-Hernandez A, Morrison SJ and Clarke MF: Prospective identification of tumorigenic breast cancer cells. Proc Natl Acad Sci USA 100: 3983-3988, 2003.

12. O'Brien CA, Pollett A, Gallinger S and Dick JE: A human colon cancer cell capable of initiating tumour growth in immunodeficient mice. Nature 445: 106-110, 2007.

13. Ricci-Vitiani L, Lombardi DG, Pilozzi E, Biffoni M, Todaro M, Peschle C and De Maria R: Identification and expansion of human colon-cancer-initiating cells. Nature 445: 111-115, 2007.

14. Takebe N, Harris PJ, Warren RQ and Ivy SP: Targeting cancer stem cells by inhibiting Wnt, Notch, and Hedgehog pathways. Nat Rev Clin Oncol 8: 97-106, 2011.

15. Zhou BB, Zhang H, Damelin M, Geles KG, Grindley JC and Dirks PB: Tumour-initiating cells: challenges and opportunities for anticancer drug discovery. Nat Rev Drug Discov 8: 806-823, 2009.

16. Dean M, Fojo T and Bates S: Tumour stem cells and drug resistance. Nat Rev Cancer 5: 275-284, 2005.

17. Zhou S, Schuetz JD, Bunting KD, Colapietro AM, Sampath J, Morris JJ, Lagutina I, Grosveld GC, Osawa M, Nakauchi H and Sorrentino BP: The ABC transporter Bcrp1/ABCG2 is expressed in a wide variety of stem cells and is a molecular determinant of the side-population phenotype. Nat Med 7: 1028-1034, 2001.

18. Schinkel AH and Jonker JW: Mammalian drug efflux transporters of the ATP binding cassette (ABC) family: an overview. Adv Drug Deliv Rev 55: 3-29, 2003.

19. Robey RW, To KK, Polgar O, Dohse M, Fetsch P, Dean M and Bates SE: ABCG2: a perspective. Adv Drug Deliv Rev 61: 3-13, 2009.

20. Madjd Z, Mehrjerdi AZ, Sharifi AM, Molanaei S, Shahzadi SZ and Asadi-Lari M: CD44 ${ }^{+}$cancer cells express higher levels of the anti-apoptotic protein Bcl-2 in breast tumours. Cancer Immun 9: 4, 2009. 
21. Carter BZ, Qiu Y, Huang X, Diao L, Zhang N, Coombes KR, Mak DH, Konopleva M, Cortes J, Kantarjian HM, Mills GB, Andreeff $\mathrm{M}$ and Kornblau SM: Survivin is highly expressed in CD34(+)38(-) leukemic stem/progenitor cells and predicts poor clinical outcomes in AML. Blood 120: 173-180, 2012.

22. Terpstra W, Ploemacher RE, Prins A, van Lom K, Pouwels K, Wognum AW, Wagemaker G, Löwenberg B and Wielenga JJ: Fluorouracil selectively spares acute myeloid leukemia cells with long-term growth abilities in immunodeficient mice and in culture. Blood 88: 1944-1950, 1996.

23. Paterson SC, Smith KD, Holyoake TL and J Jørgensen HG: Is there a cloud in the silver lining for imatinib? $\mathrm{Br}$ J Cancer 88: 983-987, 2003.

24. Gordaliza M: Natural products as leads to anticancer drugs. Clin Transl Oncol 9: 767-776, 2007.

25. Ji HF, Li XJ and Zhang HY: Natural products and drug discovery. Can thousands of years of ancient medical knowledge lead us to new and powerful drug combinations in the fight against cancer and dementia? EMBO Rep 10: 194-200, 2009.

26. Chinese Pharmacopoeia Commission. Pharmacopoeia of the Peoples Republic of China. Vol 1. Chinese Medical Science and Technology Press, Beijing, pp573-575, 2010 (In Chinese).

27. Xu YY and Yu EX: Clinical analysis of the effect of Pien Tze Huang in treatment of 42 patients with moderate or advanced liver cancer. Shanghai J Tradit Chin Med (Chin) 12: 4-5, 1994 (In Chinese).

28. Gu ZX: Therapeutical observation of advanced colon cancer. Chin Tradit Patent Med (Chin) 15: 23, 1993 (In Chinese)

29. Liu CS: Review of pharmacology and clinical application of Pien Tze Huang. Med Pharm World (Chin) 7: 64-66, 2006 (In Chinese)

30. Lin JM, Wei LH, Chen YQ, Liu XX, Hong ZF, Sferra TJ and Peng J: Pien Tze Huang-induced apoptosis in human colon cancer HT-29 cells is associated with regulation of the Bcl-2 family and activation of caspase 3. Chin J Integr Med 17: 685-690, 2011

31. Zhuang QC, Hong F, Shen AL, Zheng LP, Zeng JW, Lin W, Chen YQ, Sferra TJ, Hong ZF and Peng J: Pien Tze Huang inhibits tumor cell proliferation and promotes apoptosis via suppressing the STAT3 pathway in colorectal cancer mouse. Int J Oncol 40: 1569-1574, 2012.

32. Shen AL, Hong F, Liu LY, Lin JM, Zhuang QC, Hong ZF and Peng J: Effects of Pien Tze Huang on angiogenesis in vivo and in vitro. Chin J Integr Med 18: 431-436, 2012.

33. Shen AL, Hong F, Liu LY, Lin JM, Wei LH, Cai QY, Hong ZF and Peng J: Pien Tze Huang inhibits the proliferation of human colon carcinoma cells by arresting G1/S cell cycle progression. Oncol Lett 4: 767-770, 2012.

34. Shen AL, Chen YQ, Hong F, Lin JM, Wei LH, Hong ZF, Sferra TJ and Peng J: Pien Tze Huang suppresses IL-6-inducible STAT3 activation in human colon carcinoma cells through induction of SOCS3. Oncol Rep 28: 2125-2130, 2012.
35. Shen A, Lin J, Chen Y, Lin W, Liu L, Hong Z, Sferra TJ and Peng J: Pien Tze Huang inhibits tumor angiogenesis in a mouse model of colorectal cancer via suppression of multiple cellular pathways. Oncol Rep 30: 1701-1706, 2013.

36. Goodell MA, Brose K, Paradis G, Conner AS and Mulligan RC: Isolation and functional properties of murine hematopoietic stem cells that are replicating in vivo. J Exp Med 183: 1797-1806, 1996.

37. Golebiewska A, Brons NH, Bjerkvig R and Niclou SP: Critical appraisal of the side population assay in stem cell and cancer stem cell research. Cell Stem Cell 8: 136-147, 2011.

38. Bleau AM, Hambardzumyan D, Ozawa T, Fomchenko EI, Huse JT, Brennan CW and Holland EC: PTEN/PI3K/Akt pathway regulates the side population phenotype and $\mathrm{ABCG} 2$ activity in glioma tumor stem-like cells. Cell Stem Cell 4: 226-235, 2009.

39. Chiba T, Kita K, Zheng YW, Yokosuka O, Saisho H, Iwama A, Nakauchi $\mathrm{H}$ and Taniguchi H: Side population purified from hepatocellular carcinoma cells harbors cancer stem cell-like properties. Hepatology 44: 240-251, 2006.

40. Chua C, Zaiden N, Chong KH, See SJ, Wong MC, Ang BT and Tang C: Characterization of a side population of astrocytoma cells in response to temozolomide. J Neurosurg 109: 856-866, 2008 .

41. Haraguchi N, Utsunomiya T, Inoue H, Tanaka F, Mimori K, Barnard GF and Mori M: Characterization of a side population of cancer cells from human gastrointestinal system. Stem Cells 24 506-513, 2006.

42. Ho MM, Ng AV, Lam S and Hung JY: Side population in human lung cancer cell lines and tumors is enriched with stem-like cancer cells. Cancer Res 67: 4827-4833, 2007.

43. Mitsutake N, Iwao A, Nagai K, Namba H, Ohtsuru A, Saenko V and Yamashita S: Characterization of side population in thyroid cancer cell lines: cancer stem-like cells are enriched partly but not exclusively. Endocrinology 148: 1797-1803, 2007.

44. Patrawala L, Calhoun T, Schneider-Broussard R, Zhou J, Claypool K and Tang DG: Side population is enriched in tumorigenic, stem-like cancer cells, whereas $\mathrm{ABCG} 2^{+}$and ABCG2- cancer cells are similarly tumorigenic. Cancer Res 65: 6207-6219, 2005

45. Wu C and Alman BA: Side population cells in human cancers. Cancer Lett 268: 1-9, 2008.

46. Wu C, Wei Q, Utomo V, Nadesan P, Whetstone H, Kandel R, Wunder JS and Alman BA: Side population cells isolated from mesenchymal neoplasms have tumor initiating potential. Cancer Res 67: 8216-8222, 2007.

47. Efferth T: Stem cells, cancer stem-like cells, and natural products. Planta Med 78: 935-942, 2012.

48. Weber DA, Wheat JM and Currie GM: Cancer stem cells and the impact of Chinese herbs, isolates and other complementary medical botanicals: a review. Zhong Xi Yi Jie He Xue Bao 10: 493-503, 2012. 